高分子文集 (Kobunshi Ronbunshu), Vol. 42, No. 10, pp. 663-670 (Oct., 1985)

\title{
含フッ来セグメント化ポリゥレタンに対する䫅粒球 ならびにリンバ球の反応性
}

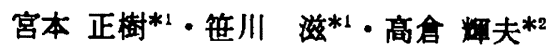

（受付 1985 年 5 月 8 日・籍查釉了 1985 年 7 月 30 日）

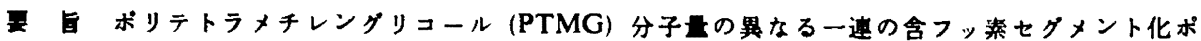

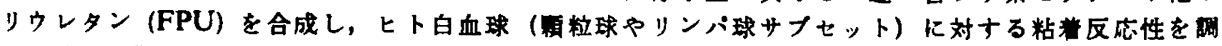
くた結果，FPUに次の特性が見いだされた。 (1)PTMG 分子量は，FPU と各細胞との相互作用を支

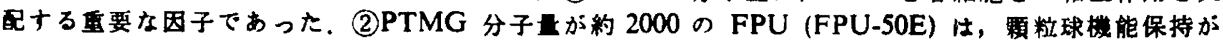

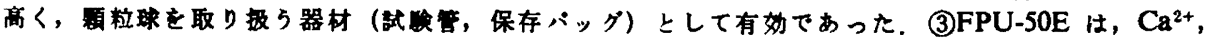
$\mathrm{Mg}^{2+}$ 共存下でリンバ球 2 大集団 ( $\mathrm{T}$ cell, B cell) の内 $\mathrm{B}$ cell を特異的に粘蒙させたが, $\mathrm{Ca}^{2+}$, $\mathrm{Mg}^{2+}$ 非存在下では B cell 粘蓄が著しく低下した。そして，2 価カチオンや接触時間などをコントロ

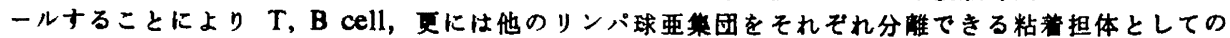
可能性が示された。これらの协果は，FPU-50Eのミクロ相分崔棈造と閶連があるものと考えられた。
\end{abstract}

\section{1 緒}

人工心满の血液ボンプ血夜回路などの医用弾性材料 火要求される特性は，绕れた力学的性質，拺久性, 成形加

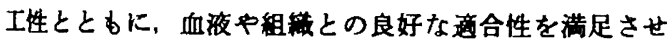
る性質である。この上らな䂓点から，七クィント化ボリ ウレタンは、これまで多くの研究者により開発，応用さ れてきたか，幾多の問題点を残している，我ヶは，生体 に不活性な瑓水性フ,素化合物の 親水一䂾水型のミク口 相分崔構造を有する含フッ秦七クィント化ボリウレタン (FPU) が、フッ素を含まない従来のセクメント化ポリ ウレタンより機械的物性, 抗血栓性とるに绩九ており， 新しい医用単性材料として有望であることを示した11,2)， 12). 更氾詳細な FPU と血液細胞との相互作用を解析し た結果，FPU は顆粒球やリンバ球に対して興味ある特 性を示し，顆粒球を取り报ら器材やリンバ球サブセット 分崔用粘着担体としてる有效であることが明らかとなっ た. そこで本報では，ボリェーテル部位として平均分子 異なるポリテトラメチレンクリコール (PTMG)を いつ一連の FPU を合成し，ヒト白血球との反応性を解 析し, PTMG 分子每と顆粒球機能保持やリンバ球サフ セットの粘着挙動との夙連について検討した.

*1 日本赤十字社中央血液七ンター研究部 $($ - 150 東京 都涉谷区広尾 4-1-31)

*2 旭硝子(株) 研究阙発部（-221 横浜市神奈川区羽沢 叮松原 1150)

\section{2 材料及び方法}

\subsection{FPU の合成及ひ試料の作䌘}

FPU の合成法については既に詳細に報告した ${ }^{12,2), 122 ． ~}$ 含フッ素ジイッシアネート $\left(\mathrm{OCNCH}_{2}\left(\mathrm{CF}_{2}\right)_{4} \mathrm{CH}_{2} \mathrm{NCO}\right)$ と平均分子量の異なる PTMG $\left(M_{n}=660,1080,2110\right.$, 2880) との反応汇よりプレポリマーを得，鎖延長剤とし てェチレンジフミンを用いて FPU（それぞれ，FPUC0E, $-20 \mathrm{E},-50 \mathrm{E},-60 \mathrm{E})$ を合成した.

各 FPUは, $10 \mathrm{ml}$ ガラス試験管 (G-2. $15 \times 100 \mathrm{~mm}$, ヘイレックスB) 及び 48 60^ッシュ(直径 250 300 $\mu \mathrm{m})$ ガラス・ビース (G, 東芝ハロティー二社製) Kシ メチルホルムアミドを用いた溶媒蒸発法によりコーティ ンクを行った．むたコントロールとして，同サイズの カララス試験管 (G-1，Larubo®，テルモ社製)を用いた。

\section{2 白血球の䀦紫}

健康人よりクエン酸採血後，直ちに白血球を dextran 法3)，顆粒球を dextran-ficoll 法年，リン八゙球を ficoll

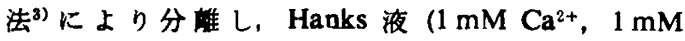
$\mathrm{Mg}^{2+}, \mathrm{pH}$ 7.4) に浮遊させた。

\subsection{FPU と白血球との相互作用の解析}

2.3.1 顆粒球の粘晢反态性及ひ機能の伻価 各 FPU コート試嵞管に顆粒球浮遊液 $\left(5 \times 10^{\circ} \mathrm{cells} / \mathrm{m} l\right.$, 純度,

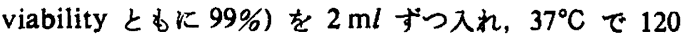
分間 incubate 後，(1)浮遊細胞数，(2)釈酸脱水素醭秦 (LDH) 漏出量， (3)粘着細胞の分布、形態変化を測定し た4). 
Table 1. Granulocytes reactivity of FPU and Glass $\left.{ }^{2}\right)$

\begin{tabular}{|c|c|c|c|c|}
\hline \multirow{2}{*}{$\begin{array}{l}\text { Sample } \\
\text { Coating }\end{array}$} & \multicolumn{2}{|c|}{ Cell loss } & \multicolumn{2}{|c|}{ LDH leakage } \\
\hline & None & Plasma & None & Plasma \\
\hline G-1 & 1.00 & $0.82 \pm 0.12$ & 1.00 & $0.92 \pm 0.08$ \\
\hline G-2 & $1.12 \pm 0.05$ & $0.73 \pm 0.02$ & $1.26 \pm 0.13$ & $1.00 \pm 0.19$ \\
\hline $00 \mathrm{E}$ & $1.76 \pm 0.12$ & $1.29 \pm 0.10$ & $1.07 \pm 0.28$ & $0.96 \pm 0.07$ \\
\hline $20 \mathrm{E}$ & $1.48 \pm 0.13$ & $0.77 \pm 0.17$ & $1.05 \pm 0.09$ & $1.04 \pm 0.02$ \\
\hline $50 \mathrm{E}$ & $1.16 \pm 0.11$ & $1.09 \pm 0.11$ & $1.01 \pm 0.19$ & $0.87 \pm 0.05$ \\
\hline $60 \mathrm{E}$ & $0.91 \pm 0.03$ & $1.11 \pm 0.26$ & $1.01 \pm 0.07$ & $1.11 \pm 0.09$ \\
\hline
\end{tabular}

a) Data are expressed as means \pm S.D. $(N=3)$. LDH, lactate dehydrogenase.

武験管の底面に粘着した細胞は，Hanks 液で 3 回りン スした後，2\%クルタルアルデヒドにて固定し，眖水，

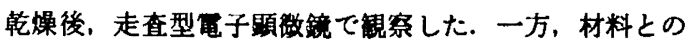
接触に伴う顆粒球機能变化は，保存 medium ${ }^{3)}$ に浮遊 させた顆粒球を各試匼管に入れ，室温 $\left(22 \pm 0.5^{\circ} \mathrm{C}\right)$ て 24 時間, 連続回転振とう (50 rpm, Coulter Mixer(B)

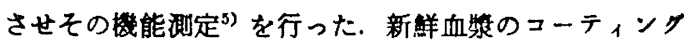
は, $5 \%$ 血漿-Hanks 液 $\left(\mathrm{Ca}^{2+}, \mathrm{Mg}^{2+}\right.$ free $)$ を各試験管 に入れ $37^{\circ} \mathrm{C} て ゙ 5$ 時間 incubate 後, リンスして串験に 用いた。

2.3.2 カラム法による頛粒球/リンパ球の粘析反忘性 の解析 FPU ロート・ビース $1.0 \mathrm{~g}$ を塩化ピニル・チ ニーブ (川澄 (株) 制, 内径: $3 \mathrm{~mm}$, 長さ: $100 \mathrm{~mm}$ ) K 最密充てんし，カラムを作製した．カラムは， Hanks 液で 1 晚ブライムした. 白血球浮遊液 $\left(1 \times 10^{7} \mathrm{cells} / \mathrm{ml}\right.$, 顆粒球純度 $68 \pm 4 \%$ ，viability $99 \%) 1.0 \mathrm{ml}$ を上記力 ラムトシリンジ・ポンフ (model 341, Orion Research 社製または医学畫院器機 (株) 製) を用いて一定流速 $(0.5 \sim 6.0 \mathrm{~m} / / \mathrm{min}$, 室温) で流し, 直ちに Hanks 液 $1.0 \mathrm{ml}$ を同一条件下で通過させ，リンスを行った．細 胞数は Coulter Counter®により，顆粒球とリンハ球 の純度は Coulter Channelyzer@による粒度分布より 測定しだ)。各細胞の粘着率は，カラム流出前後の細胞 数の比較から算出しだ)。なお，ビーズを含まないカラ ムへの各細胞の粘着は，ほとんど認められなかった。

2.3.3 カラム法によるリンパ球サフセットの粘些反 太性の解析 リンハ球㐿遊夜 $\left(1 \times 10^{7} \mathrm{cells} / \mathrm{m} l\right.$, viability 99\%) $1.0 \mathrm{ml}$ を 2.3.2 と同槏にカラムに通過させ, 各 細胞粘着率を算出した.リンバ球サフポビュレーション (T cell, B cell, Double Marker (D) cell, Null (N) cell, Mononuclear Phagocyte (P) cell) の分類は，ボ リフクリルアミドゲル粒子に抗ヒト免疫クロフリンを結 合させた immuno-beads とノイラミニダーゼ処理した ヒッジ赤血球を同時併用 (TBP-5, 望星サイェンス(株) 製）したロぜット形成法により算出しだ)。各細胞比率 は, T cell, $50 \pm 2 \% ; B$ cell, $26 \pm 4 \% ; D$ cell, $6 \pm$

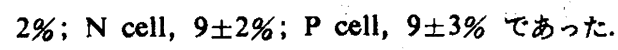

\section{3 結 果}

\section{1 西粗球の粘费反応性と機能保持}

Table 1 K, 各材料に対寸る浮遊顆粒球数の減少と LDH 漏出量を示した. 血洯コート及び末ュート下で测 定し，末コートガラス（G-1）の值を 1.0 として相対的 に表した. FPU K対する細胞数の減少率は，ガラス (G-1，G-2）と同しかあるいはガラスよりる高かった。 血攻非存在下で, FPU 中の PTMG 分子量の增加化伴 い細胞の損失は低下する傾向を示し，血墏存在下では FPU-20E が最も少なかった. 細胞膜破壤を示す LDH

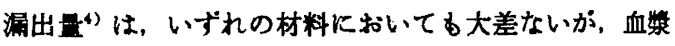
コート FPU-50E が比較的低かった. ガラスを比べる と、G-1 より G-2 の方が LDH 漏出量は高い佰向を示 した.

粘着顆粒球は，ガラス表面に single な状的で一侎に 分布し, spreading が進んでいた(Fig. 1 (A)，(B)). FPU 表面は，細胞の粘着部分之非粘着部分が存在 し (電子影微鏡 写真は比較的粘着細胞の多い部分を示し た)，粘着細胞か round な形態で観察された (Fig. 1 (A), (B)). FPU 表面の粘着細胞は、リンスによって容 易に脱着されやすく， PTMG 分子量の增加に伴って粘 羞細胞数が低下した，これらの結果は，血浆の有無にか かわらず同梾な傾向を示した。

各材料が顆粒球機能に及注す影率を調べために，顆 粒球を血等含有 medium に浮遊させ，室温 $\left(22 \pm 0.5^{\circ} \mathrm{C}\right)$ で 24 時間連綄的に材料表面上接触させ, 顆粒球の性状 を謤価した．このよらな条件下では，浮遊細胞数 (Table 2) と平均細胞体楼 $(\mathrm{MCV})^{3)}$ は，いずれの材料炕いて む新鮮細胞と汪とんど変わらなかった．顆粒球の代表的 な機能であり，最も機能損侮を受けやすい遊走能》は (Table 2)，LDH 漏出量 (Table 1) が最も低いFPU$50 \mathrm{E}$ で高く，新鮮細胞の約 $60 \%$ の活性を示したが，他 の材料では 50\%を下回った.これらの結果から，FPU 中の PTMG 分子量は, 顆粒球機能保持を支民す万重要 
含フッ秦セグメント化ポリウレタンに対する顆粒球ならびにリンハ球の反応性

(A) none coated
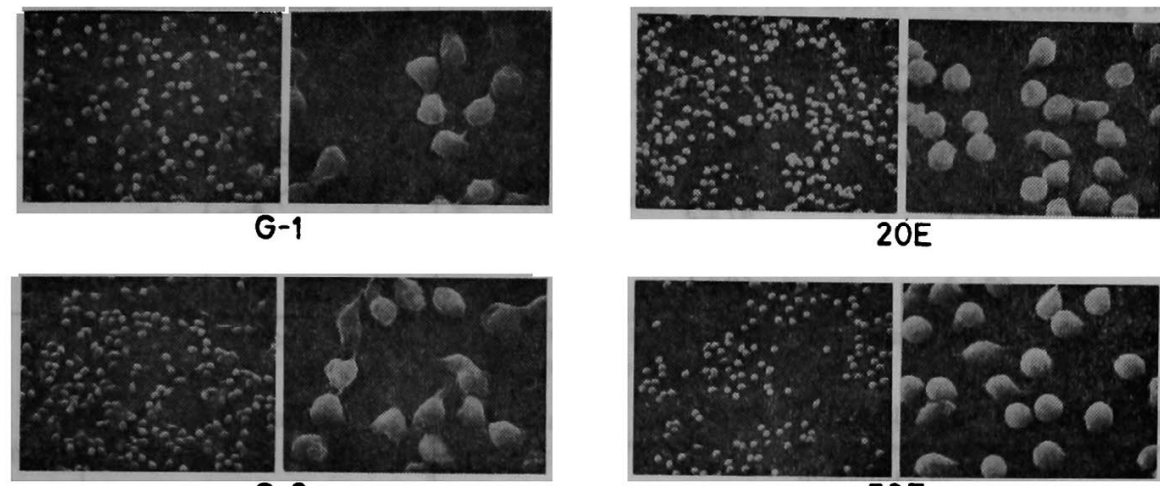

G-2

$50 \mathrm{E}$
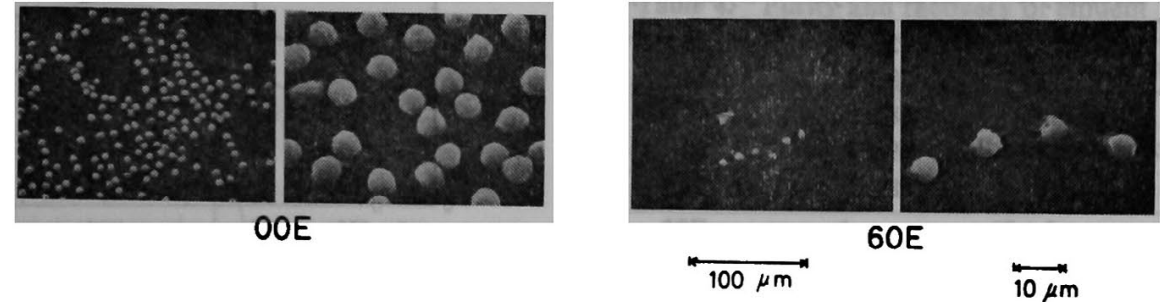

(B)

plasma coated
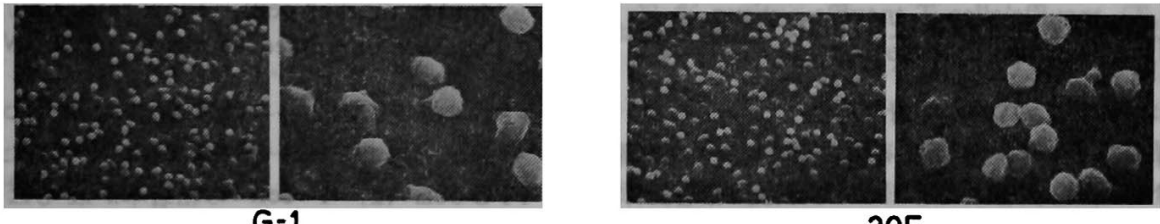

$20 E$
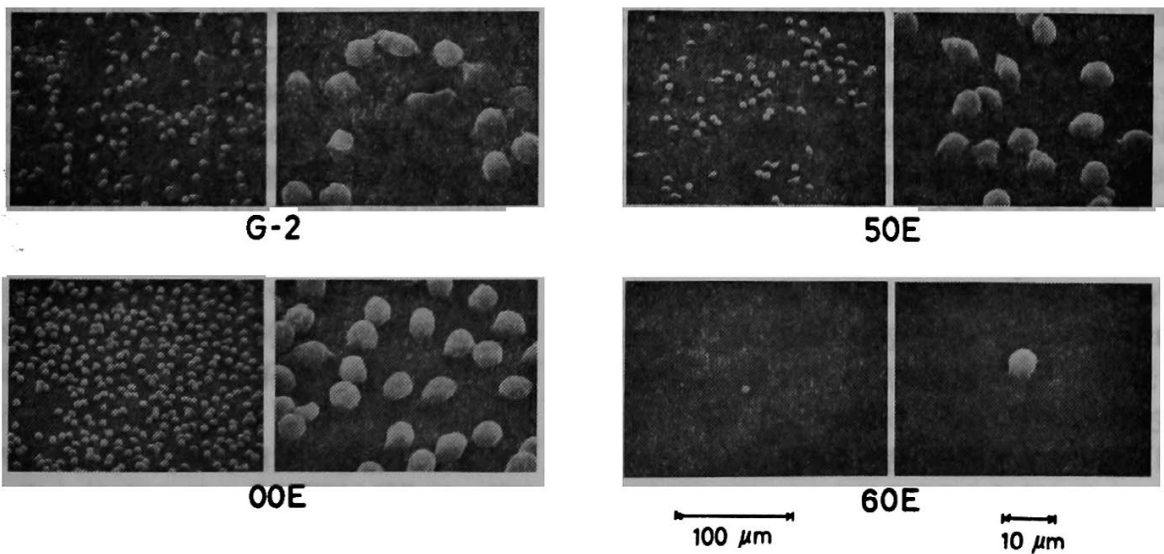

Fig. 1. Granulocytes adhered on the surfaces of various materials with (B) or without (A) plasma at $37^{\circ} \mathrm{C}$ for $120 \mathrm{~min}$. 
Table 2. Changes of cell counts and chemotaxis of stored granulocytes in various test tubes for $24 \mathrm{~h}$ at $22^{\circ} \mathrm{C}$ a

\begin{tabular}{ccc}
\hline Sample & $\%$ Cell counts & $\%$ Chemotaxis \\
\hline G-1 & $99 \pm 1$ & $46 \pm 5$ \\
G-2 & $102 \pm 1$ & $39 \pm 1$ \\
$00 E$ & $99 \pm 1$ & $47 \pm 5$ \\
$20 E$ & $100 \pm 1$ & $46 \pm 4$ \\
SOE & $97 \pm 2$ & $60 \pm 1$ \\
\hline
\end{tabular}

a) Data are expressed as means \pm S.D. $(N=3)$.

Table 3. Leukocytes adhesion on FPU ${ }^{\text {a) }}$

\begin{tabular}{lccc}
\hline \multirow{3}{*}{ Sample } & \multicolumn{3}{c}{$\%$ Adhesion } \\
\cline { 2 - 4 } & Leukocyte & Granulocyte & Lymphocyte \\
\hline G & $72 \pm 1$ & $75 \pm 1$ & $59 \pm 2$ \\
$00 \mathrm{E}$ & $73 \pm 1$ & $78 \pm 2$ & $54 \pm 2$ \\
$20 \mathrm{E}$ & $63 \pm 6$ & $68 \pm 5$ & $45 \pm 8$ \\
$50 \mathrm{E}$ & $64 \pm 3$ & $69 \pm 3$ & $50 \pm 5$ \\
$60 \mathrm{E}$ & $65 \pm 1$ & $68 \pm 1$ & $53 \pm 1$ \\
\hline
\end{tabular}

- Data are expressed as means \pm S.D. $(N=3)$. Flow rate, $3 \mathrm{ml} / \mathrm{min}$.

な因子であり，PTMG 分子量が約 2000 の FPU-50E は，血漿存在下において顆粒球機能保持に有効であるこ とが分かったまた，ガラスを比較すると，G-1 より LDH 漏出国の高かった G-2 は (Table 1)，遊走能が 40\%を下回り，著しい機能低下を示した。

\section{2 頛䄈球とリンパ球の站券反応性}

カラム法により FPUに対する顆粒球とリンハ球の粘 着性を調へ，FPU の顆粒球/リンバ球分離用粘着担体 としての特性を評価した (Table 3). いずれの材料も維 白血球粘着率か～60 70\%，顆粒球粘着率か; $70 \sim 80 \%$, そしてリンハ球粘着率か：45６0\% と大差なく，また顆 粒球/リンパ球 粘着比 (顆粒球粘着率/リンハ球粘着率) が 1.3〜1.5 と晁著な粘着選択性は認められなかった。 しかし，ヒト血淩アルフミン (HSA) をカラムに precoat4) した場合，末コート系と比鉸して，各細胞の粘着 率は，10〜20\% ほと低下したか，顆粒球/リンハ球粘 着比は，ガラス (G) を除いて HSA コーティングよ り $0.5 \sim 0.6$ 高まった. 一方, 流速の増加により各細胞 の粘着率は低下したが，顆粒球/リンパ球 粘着比はほと んど変わらなかった。

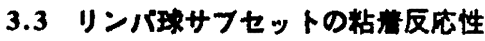

リンパ球サブセットの粘着性を，カラム法により室温 で調べた、リンバ球 (L) 粘着率は， $45 \%$ 前後と材料間 の差は、汪とんど認められなかった (Fig. 2). FPU-00E は， T cell， B cell の粘着禹が同程度であるが，他の

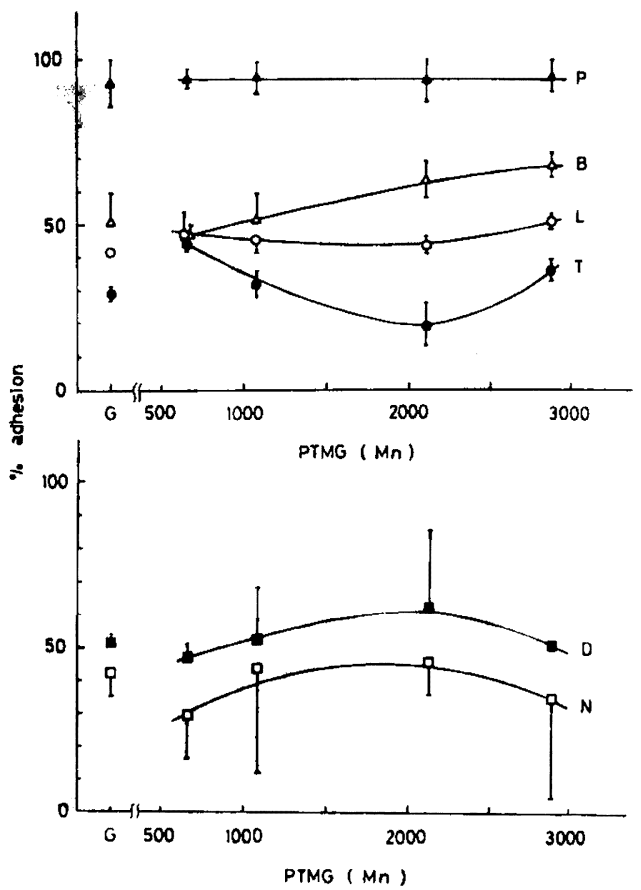

Fig. 2. Effects of molecular weight of PTMG in FPU on lymphocytes sub-sets adhesion:

O, L (lymphocyte);, T (T cell); $\triangle$, B (B cell); $\triangle, P$ (phagocyte cell); $\square, \mathbf{N}$ (null cell); $\mathbf{n}, \mathrm{D}$ (double marker cell). Flow rate, $1 \mathrm{ml} / \mathrm{min}$. Date are expressed as means \pm S.D. $(N=3)$.

FPU は, PTMG 分子吾の增加により B cell の粘着率 を禹め，逆に T cell の粘着率を低下させた．その中で， FPU-50E は, $T$ cell の粘着率が取低く, B cell/ $\mathrm{T}$ cell 粘着比 (B cell 粘着率/ T cell 粘着率) を大愊 增加させた，一方， $\mathrm{P}$ cell, $\mathbf{N}$ cell, $\mathrm{D}$ cell の粘着率 は，いずれのビースにおいても大差なく，それぞれ約 90\%, 約 40\%, 約 50\% であった.

Fig. 3 に,リンハ球の 2 大集団, $\mathrm{T}$ cell, B cell の粘 着に及ぼすカラム流速の影管を示した，材料によってカ ラム流速に対する $\mathrm{T}$ cell, B cell の粘着バターンが簧 なり，次の 3 群に分類できた，カラム流速の增加に伴い (1)G (ガラス) タイブ: B cell 粘着は低下, T cell 粘着 はほとんど変わらない、(2)FPU-00E, FPU-20E のタイ ブ: B cell 粘着と T cell 粘着はともに低下 (3FUP-50E, FPU-60E のタイブ：B cell 粘着ははとんど変わらない か， T cell 粘着は低下. この結果から, FPUの PTMG 分子青とカラム流速が B cell/T cell 粘着比に及ぼす好 果を Fig. 4 に示した. PTMG 分子旺が約 2000 の FPU-50E は，いずれの流速において も B cell/T cell 粘着比が他の材料より高く，またカラム流速の增加によ 

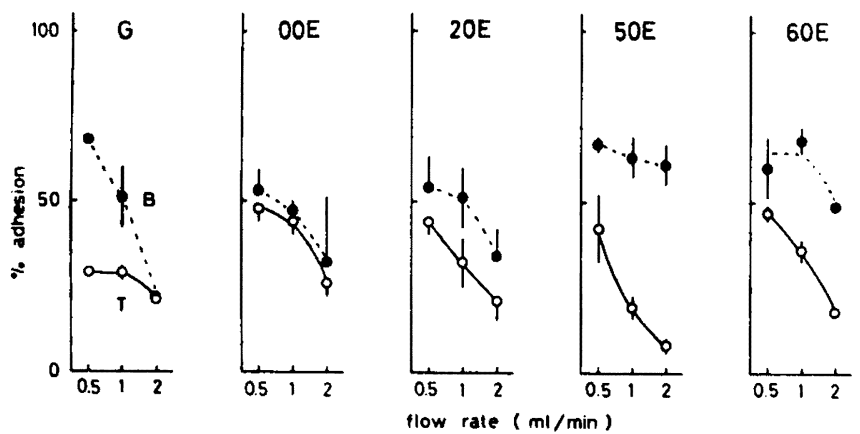

Fig. 3. Effects of flow rate on $T$ cell $(-O-)$ and $B$ cell $(\cdot---)$ adhesion. Data are expressed as mean \pm S.D. $(N=3)$.

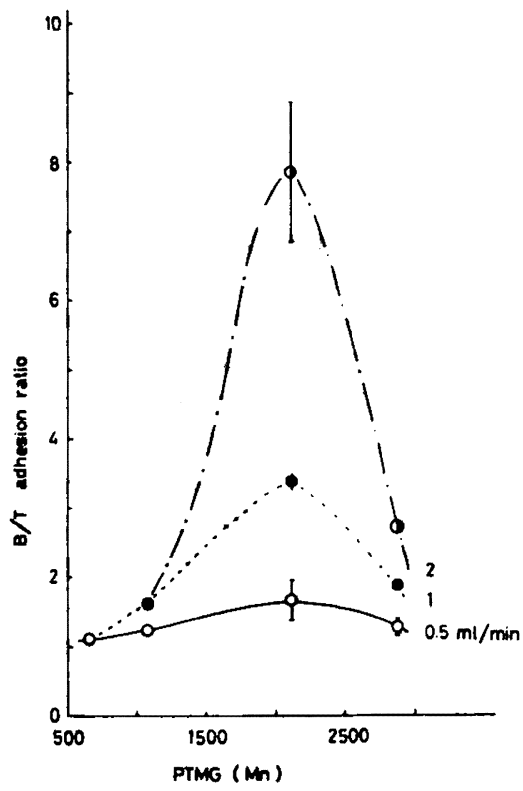

Fig. 4. Effects of molecular weight of PTMG in FPU and flow rate on $B$ cell/ $T$ cell adhesion ratio:

$-0-, 0.5 \mathrm{ml} / \mathrm{min} ;----, 1 \mathrm{~m} / / \mathrm{min} ;--0--, 2 \mathrm{ml} /$ min. Data are expressed as means \pm S.D. $(N=3)$.

り著しく高まった。一方，FPU-50E より PTMG 分子 钟高くても，低くても B cell/T cell 粘着比にきわた った奻果はみられなかった。

Table 4 K，各ビースカラムを用いたときの流出 $\mathrm{T}$ cell の回收率と純度を示した. FPU-50E は, 流速 $1 \mathrm{~m} / \mathrm{min}$ に扎いても $\mathrm{T}$ cell の純度, 回收率ともに約

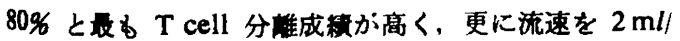
$\min$ К高めると, 回収率 90\% 以上で, $\mathrm{T}$ cell の分離
Table 4. Purity and recovery of effluent $T$ cells ${ }^{a)}$

\begin{tabular}{cccc} 
Beads & $\begin{array}{c}\text { Flow rate } \\
(\mathrm{ml} / \mathrm{min})\end{array}$ & \multicolumn{2}{c}{ Effluent $\mathrm{T}$ cells } \\
\cline { 3 - 4 } & & $\begin{array}{c}\% \\
\left.\text { Purity }{ }^{\mathrm{b}}\right)\end{array}$ & $\begin{array}{c}\% \\
\text { recovery })\end{array}$ \\
\hline G & 1 & $73 \pm 6$ & $71 \pm 2$ \\
$00 \mathrm{E}$ & 1 & $67 \pm 2$ & $56 \pm 6$ \\
$20 \mathrm{E}$ & 1 & $73 \pm 7$ & $68 \pm 7$ \\
$50 \mathrm{E}$ & 1 & $81 \pm 4$ & $81 \pm 3$ \\
$60 \mathrm{E}$ & 1 & $72 \pm 2$ & $64 \pm 3$ \\
$50 \mathrm{E}$ & 2 & $82 \pm 4$ & $92 \pm 2$ \\
\hline
\end{tabular}

a) Data are expressed as means \pm S.D. $(N=3)$. b) $\%$ purity $=$ effluent $\mathrm{T}$ cells/effluent $(\mathrm{T}$ cells $+\mathrm{B}$ cells). c) $\%$ recovery =effluent $\mathrm{T}$ cells/initial $\mathrm{T}$ cells.

用材料として有奻であった．他の FPU の分離成曗は， FPU-20E と FPU-60E か G と同程度, FPU-00E か $\mathbf{G}$ 上り低く，それぞれ分離用材料として不高当であっ た.

Fig. 5 は, 各種りンハ球の FPU-50E への粘着と 2 価カチオン及び流速の影䇾を示した，各細胞の粘着率 は，2 価カチオン存在下 (1 $\left.\mathrm{mM} \mathrm{Ca}^{2+}, 1 \mathrm{mM} \mathrm{Mg}^{2+}\right)$, カラム流速 $1 \mathrm{ml} / \mathrm{min}$ に猢各細胞の粘着率をそれそ れ 1.0 として表した. 同一流速下において $T$ cell, $N$ cell, D cell の粘着率は, 2 価カチオンの有無にかかわら ずほぼ同しであったが, B cell の粘着率は $\mathrm{Ca}^{2+}$ と $\mathrm{Mg}^{2+}$ の除去により著しく減少した. P cell 粘着は，2 価カ子 オンが存在する場合，流速の影需をほとんど受けない か，非存在下かつ高流速 $(2 \mathrm{ml} / \mathrm{min})$ の场合大幅に低下 した. $\mathrm{N}$ cell，D cell は，流速によらずほほ同一の粘着 率を示した，以上の結果から，2 価カチオンと流速の組 合せにより，各種細胞の粘着を調整できることが分かっ た. B cell と T cell の粘着性を比㕮すると， 2 価カチ オン存在下では FPU-50E は, B cell/T cell 粘着比が 


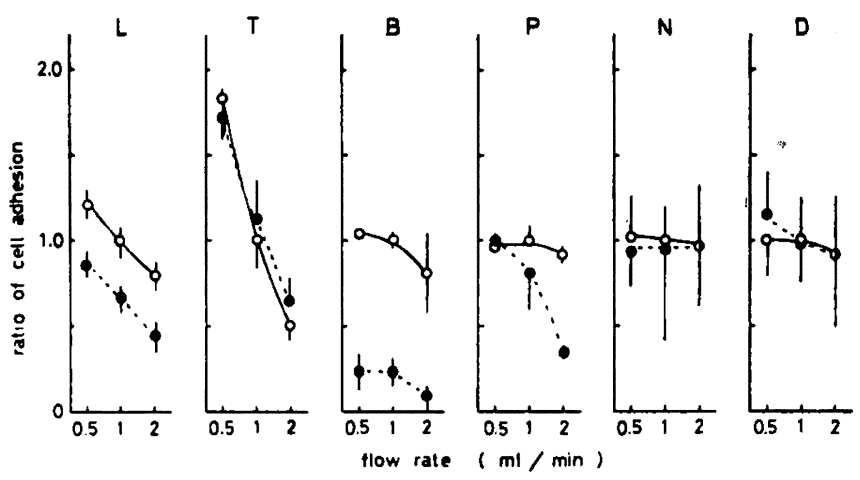

Fig. 5. Effects of divalent cations and flow rate on lymphocytes sub-sets adhesion to FPU-50E: $-\mathrm{O}$, with $1 \mathrm{mM} \mathrm{Ca}^{2+}+1 \mathrm{mM} \mathrm{Mg}^{2+} ;--\bullet$, without $\mathrm{Ca}^{2+}$ and $\mathbf{M g}^{2+}$. Data are expressed as mean \pm S.D. $(N=3)$.

高く(Fig. 4)，2 価カチオン非存在下では，低流速(0.5 $\mathrm{ml} / \mathrm{min})$ K扰いて逆に $\mathrm{T}$ cell/B cell 粘着比 $(2.8 \pm 1.2)$ が高くなり，目的に応した練胞分倠の可能性が示され た.

\section{4 考察}

我々は, PTMG 分子量約 2000 の FPU (FPU-50E) が抗血拴医用弾性材料として優れていることを既に報告

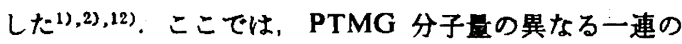
FPU ととト白血球との相互作用を調べた。その結果， FPU-50E は，血液細胞の中でも異物（バクテリア，医 用材料なと）に対する反店性が極めて高い(顆粒球”之材 料との接触に伴ら細胞損侮を最も抑制させた．したがっ て顆粒球を取り扱ら器材け）市として有効であることが示 された。 また，FPU-50E は， $\mathrm{Ca}^{2+}, \mathrm{Mg}^{2+}$ 共存下で， リンハ球 2 大集団である B cell の選択的粘着を起こ し，効率良い，T cell，B cell の分離用粘着担体として 期待できた，FPU-50E は，耐久性，成形加工性にむ传

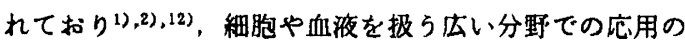
可能性を示した.

各細胞が FPU との接触により生ずる細胞粘着反応の 差がいかなる機序で発㺺するかは不明であるが, PTMG 分子量の異なる FPU の顆粒球機能保持性やリンハ球サ ブセットの分崔成絽は，FPU の相分離棬造の大きさと その傾向が類似していた，すなわち，各 FPU 仕数 $10 \AA$ の極めてミクロな相分崔構造を有しており，PTMG 分 子量の增加によりンフトセクィント長(酎)が增し，それ に伴い分相の大きさが增す傾向を示すことが透過型䉓子 影徽鏡により钼察されている(122，12)。そして, FPU-50E は，ミク口相分離構造が比的大きく、はっきりしてい た. 一方，FPU-60E は， OsO4による染色性が劣り，
明確なミクロ構造は認められなかった。 また，各 FPU の水に対する接触角は，80度前後之材料間の差異は認め られなかった。

ミクロ相分離搆造を有する表面が細胞との接触による 活性化を抑制することは，片岡ら日)により見いたされて いる.すなわち，ある大きさのミク口相分離檴造を持つ 高分子材料は接触した細胞に，障害を与えることなく， intact に近い状態を耯持する機能 (capping control) か あると考えられている。

FPU-50E は，白血球の各細胞に対する粘着反応性か 大きく異なった．これら粘着挙動の違いは、細胞が本来 有する細胞膜の性状，2 価カチオンや血筤タンパクの有 無, 接触頻度（カラム流速や振とう）などによって細胞 の活性化状隹（運動性，機能性）が細胞の種頪によって 妙妙に異なり，材料との相互作用に差が生したすのと考 察される。そして，細胞浮遊夜の種類，温度などをコン トロールすることにより，特定の緇胞たけをその目的に 応して選択的に反応させ，逆に特定の細胞だけ反応㗗弱 めることの可能性が示された. FPU-50E の顆粒球機能 保持に及ぼす血奬の役割については明らかでない。:

ガラス（㜞質ガラス）は、シリコンやボリ塩化ビニル などの沉用高分子材料上り顆粒球機能保持が良好であ る゙、軟質ガラス (G-1) と硬筫ガラス (G-2)を比笠する と，前者の方が顆粒球機能保持は高かった (Table 2). この原因として，两者の陰性軍荷，ナトリウムイオン含 有量などの違いが挙げられる。細胞培養の際には，上达 の理由により軟䓄ガラスの方が細胞の粘着・增䈌のため に優れていることが報告されている゚。. また，Fig. 3 に 示したよらに，ガラス (G，㜞筫ガラス）に対する T cell 粘着率は，一般的に低いか，流速の影需をはとんど 受けなかった。この $\mathrm{T}$ cell 粘着機粸は，不明であるか， 


\section{含フッ秦セグメント化ポリウレタンに対する顆敉球ならびにリンパ球の反応性}

主氏 $\mathrm{T}$ cell とがラとの静䉓的相互作用に基のくとも 考えられる.これらの結果から，材料のスタンダートと はるガラスの選択には十充注意が必要である。

リンメ゙球サブセットの分誰は，近年の生医分野におけ ろ検査・診断・治療などに不可欠であり，迅速かつ簡便

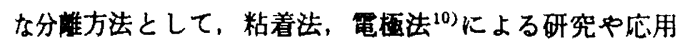
が棈力的に行われている゙，11が，リンハ球サブポピュレ ーション算出法（多くは，B cell のみを蛍光抗体法によ 算出）も十分とはいえない，我々は，ヒト白血球に対 する纫用を示し，更に混合ロぜット法によりリンパ球の 5 集団をそれそれ算出した，従来 T, B cell 分離用材料 として広く用いられてきたナイロン轼稚カラムは，煩雑 な準備や操作を要し，細胞の選択性，回収率など，多く の問題点を残している4)、11). FPU-50E による T cell の 分離 (Table 4) は，またまた渾足できる成綨ではない が，今後 T cell の純度を更に向上させる方法として， カラム長の增加，流速のコントロール，温度の上昇， 2 価カチオンの組合せなどによる改善が考えられる. FPU-50E に粘着した練胞は，いずれる round の形態を 保持しており, 溶離液の $\mathrm{pH}, 2$ 価カチオンのキレート 戍，イオン强度などを変えることでンフトに脱着・回収 されるすのと考えられる，今後は，これらの課題を解决 するとともに，FPU のミク口相分噰棈造と各細胞の粘 着反応性との関連を明らかにする必要がある。

付 記本研究の内容は, 第 14 回医用高分子シンポ ジウム(1985 年 4 月, 東京)で発表した。本研究に際 し，種々のこ眍感をいただきました中央血液たンタ一徳 永栄一所長に感骬いたします。

\section{文 㱆}

1) 加藤正雄, 高倉䊮大, 西村啓道, 山辺正影, 岡 野光夫，片岡一則，桜井端久，第 32 回漓分子

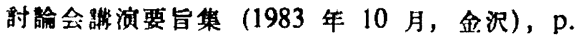
1999.

2) 高合知夫, 加藤正雄, 有機合成化学, 42,822 (1984).

3) A. Böyum, Scand. J. Clin. Lab. Invest., Suppl., 97, 51 (1968).

4) 宫本正椹，䈎川滋，䄉維と工業，39，411 (1983).

5) 宮本正樹，笹川湢，日本䡆血学会雑誌，29， 612 (1984).

6）宫本正樹，本田恶治，笹川泫，第 10 回医用 两分子シンポジム撛演要旨集(1980 年 10 月， 東京)，p. 29.

7)宮本正楖，篗川滋，徳永栄一，血液事業，5, 213 (1982).

8) 片岡一則, 鹤田襀二・榄井端久絧，“パイオマ テリアルサイエンス第 1 集”，化学の領城，增 刊 134 少，南江堂，東京 (1982), p. 93.

9) J.P. Trinkaus, 岡田暂雄監砡, “細胞行動と器 官形成”，丸善，東京 (1973)，p. 116.

10）由良洋文, 大道高弘, 高標洋介, 赤池敏宏, 青 柿良一, 人工腹器, 14, 381 (1985).

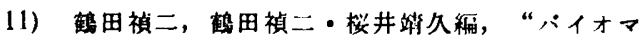
テリアルサイエンス第 2 集”, 化学の領域, 增 刊 135 多, 南江堂, 東京 (1982), p. 155.

12) M. Kato, T. Takakura, M. Yamabe, T. Okano, K. Kataoka, Y. Sakurai, K. Imachi, and K. Atsumi, Prog. Artif. Organs, 1983, 2, 858 (1984).

Interactions between Fluorine-Containing Segmented Polyurethanes and Human Leukocytes (Granulocytes and Lymphocytes Sub-Sets)

Masaki MiYamoto*1, Shigeru SaSaKawa*1, and Teruo TAKaKura*2

${ }^{* 1}$ Department of Research, Central Blood Center, Japanese Red Cross (1-31, Hiroo 4-chome, Shibuya-ku, Tokyo, I50 Japan)

${ }^{* 2}$ Research \& Development Division, Asahi Glass Co., Ltd., (1150, Hazawa-cho, Kanagawa-ku, Yokohama, 221 Japan)

To examine the interactions between fluorine-containig segmented polyurethanes (FPUs) and human leukocytes (granulocytes and lymphocytes), a series of FPUs was synthesized from poly(tetramethylene glycol) (PTMG) with average molecular weight from 660 to 2880 . The molecular weight of PTMG of the soft segment was important factor for adhesion behaviour of leukocytes, and FPU-50E, prepared from PTMG of 2110 in molecular weight showed excellent properties as a new biomaterial. The results were as follows. (1) FPU-50E had a high degree of granulocytes compatibility and been found to be useful in the materials for centrifuged tubes, test tubes, and storage containers for granulocytes. (2) FPU-50E was able to adhere B cells selectively from two major lymphocytes sub-sets in the presence of $\mathrm{Ca}^{2+}$ and $\mathrm{Mg}^{2+}$, but decreased $B$ cells adhesion greatly in the absence of these cations. By the control of divalent cations and contact periods with cells, FPU-50E was found to have possibility of material for separation of $T$ and $B$ cells, and more other lymphocytes sub-sets by adhrence chromatography. These efficiency of FPU-50E might be 
correlated to have microphase separated structures of hydrophobic domains of fluorocarbone chains and hydrophilic domains of polyether chains.

KEY WORDS Fluorine-Containing Segmented Polyurethane / Poly (tetramethylene glycol) / Leukocyte / Granulocyte / Cell Compatibility / Lymphocyte Sub-Sets / Cell Separation / Adhesion / Biomaterial / (Received May 8, 1985: Accepted July 30, 1985)

[Kobunshi Ronbunshu, 42 (10), 663-670 (1985)] 